The Agriculturists 16(2): 75-87 (2018) ISSN 2304-7321 (Online), ISSN 1729-5211 (Print)

A Scientific Journal of Krishi Foundation

Indexed Journal

DOI: http://dx.doi.org/ 10.3329/agric.v16i02.40345

Impact Factor: 0.568 (GIF, 2015)

\title{
Efficacy of Trichoderma against Colletotrichum capsici Causing Fruit Rot Due to Anthracnose of Chilli (Capsicum annum L.)
}

\author{
M. A. Rahman ${ }^{1}$, T. H. Ansari ${ }^{2}$, M. F. Alam ${ }^{1}$, J. R. Moni ${ }^{1}$ and M. Ahmed ${ }^{2}$ \\ ${ }^{1}$ Department of Botany, University of Rajshahi, Rajshahi-6205, Bangladesh \\ ${ }^{2}$ Plant Pathology Division, Bangladesh Rice Research Institute, Gazipur 1701, Bangladesh \\ *Corresponding author and Email: tahmidhansari@yahoo.com
}

Received: 25 September 2018

Accepted: 25 December 2018

\begin{abstract}
Five Trichoderma species/strains, Trichoderma virens IMI-392430, T. pseudokoningii IMI-392431, T. harzianum IMI-392432, T. harzianum IMI-392433 and T. harzianum IMI-392434 were tested against anthracnose and fruit rot of chilli. Effect of Trichoderma species in suppressing anthracnose and fruit rot as well as the growth and yield of chilli were evaluated. Seven treatments consisting of five Trichoderma strains, one Colletotrichum capsici and control were used as seed treatments. Chilli seeds were treated with spore suspension or secondary metabolites of each Trichoderma species/strain and $C$. capsici separately. Mixture of suspension of each Trichoderma species/strain with C. capsici was also used as spore suspension or secondary metabolites. Percent fruit infection in the control treatment was found almost similar to the treatment that contained $T$. viridae and $T$. pseudokoningii spore suspension or secondary metabolites. T. harzianum strains alone suppressed fruit infection (\%) significantly. Further all the Trichoderma species/strains reduced the fruit infection (\%) than the diseased control even when seeds were treated with Trichoderma separately mixing with $C$. capsici. Spore suspension of $T$. harzianum IMI-392433 was found much more effective against $C$. capsici which suppressed $95.8 \%$ and $79.6 \%$ fruit infection respectively under natural (without $C$. capsici) and high inoculum pressure of $C$. capsici. All the tested Trichoderma species/strains showed higher plant growth and increased fruit yield irrespective of rest of the treatments. It was found that Trichoderma strains control chilli fruit rot significantly but high inoculum pressure of $C$. capsici reduced fruit yield drastically. Among the treatments, spore suspension of T. harzianum IMI-392433 increased the fruit yield $83.6 \%$ and $76.5 \%$ per plant compared to spore suspension of $C$. capsici and control treatments, respectively. These results implied that $T$. harzianum IMI-392433 can effectively control fruit rot of chilli caused by C. capsici through host resistance and antifungal metabolite activity. The fruit yield was increased due to the influence of T. harzianum IMI-392433 on vigorous physiological growth of plants as well as efficacy against the disease.
\end{abstract}

Keywords: Anthracnose fruit rot, Biological control, chilli, Colletotrichum capsici, Trichoderma.

\section{Introduction}

Chilli (Capsicum annum L.) is an important spice generally used for food preparation in south-east Asia including Bangladesh. It is cultivated around 166 ha and produced 141 metric tons in 2000-2001 (Barua et al., 2009). Anthracnose incited by Colletotrichum spp. is one of the severe diseases of chilli. Two species, 
Rahman et al. /The Agriculturists 16(2): 75-87 (2018)

namely $C$. capsici and $C$. gloeosporioides were known earlier to cause Anthracnose in chilli. However $C$. capsici is the most predominant species in the major chilli growing areas in Bangladesh. The fungus is both internally and externally seed-borne (Ramachandran, 2007). It also survives on the stems and branches causing die-back symptoms. This fungus causes severe damage on chilli fruits in both pre- and post harvest stages and more than $50 \%$ of the crop losses observed (Pakdeevaraporn et al., 2005). In tropical countries, high moisture condition due to monsoon rain during June-October favors sporulation of $C$. capsici which enhances the fruit rot disease incidence and helps outbreak of the disease.

Fungicide is most commonly used as a treatment to manage, but there is a need for non-chemical methods of control to avoid the adverse effect of toxic chemicals on the environment. Biological control of plant pathogens by microorganisms has been considered a more natural and environmentally acceptable alternative to the existing chemical methods (Baker and Paulilitz, 1996). Biological control of plant pathogens has been shown to have potential to control many diseases in plantations. Chaetomium, Penicillium and Trichoderma species are biological control agents that have the potential to control plant diseases (Soytong, 2005). The antagonistic activity of Trichoderma species against plant pathogens has been studied extensively (Hjelijord et al., 2001; Etabarian, 2006). Trichoderma produced secondary metabolites such as harzianic acid, alamethicins, tricholin, peptaibols, antibiotics, 6-penthyl- $\alpha$-pyrone, massoilactone, viridin, glioviridin, gliovirin, glisoprenins, heptelidic acid, pentyl pyrone, gliotoxin, trichorzianines and oxazole which have antifungal properties (Di Pietro et al., 1993; Lee et al., 1995; Chet et al., 1997; Intana, 2003; Vey et al., 2001).

A number of commercial formulations, based on $T$. harzianum and T. virens, are available for soil borne and foliar disease control of horticultural crops (Samuels, 1996; Etabarian, 2006). T. harzianum isolate, $\mathrm{T} 39$, is the active ingredient of Trichodex, which is reported to control Botrytis grey mold on a range of crops (Elad, 1994). T. harzianum has been evaluated for the control of black seed rot disease of oil palm sprouted seeds in Nigeria (Eziashi et al., 2007). Therefore, biological control becomes important in integrated disease management for improved plant production. This finding suggested that certain strains of Trichoderma can induce systemic and localized resistance to several plant pathogens (Yedidia et al. 1999, 2000).

In this study, we therefore, investigated the effect of Trichoderma strains to control anthracnose and fruit rot of chilli under low and high inoculum pressure of $C$. capsici. The growth and yield of chilli was also evaluated to elucidate the influence of Trichoderma against fruit rot of chilli.

\section{Materials and Methods}

The experiment was conducted at Botanical Garden of Rajshahi University, Rajshahi, Bangladesh in pot culture condition. The efficacy of Trichoderma species in controlling chilli fruit rot due to anthracnose caused by Colletotrichum capsici was evaluated and the growth and yield of chilli was also investigated.

\subsection{Sterilization of soil}

Soil was collected from the research field of Rajshahi University campus and sterilized with formaldehyde (formalin: water; 1:50 v/v) and covered with polythene sheet for 24 hours. Then the soil was allowed to dry for disappearance of formaldehyde odor. After 30 days of sterilization, soil was put in the earthen pot $(30 \times$ $20 \mathrm{~cm}$ ). To allow flowing of excess water, $2 \mathrm{~cm}$ hole was made from the bottom of the pot.

\subsection{Seed collection}

Chilli variety "Bogra local" was collected from Spices Research Centre, Bogra, Bangladesh. Disease free healthy seeds were selected for use in this experiment. 


\subsection{Sources of Trichoderma}

Five Trichoderma strains namely; $T$. virens IMI392430, T. pseudokoningii IMI-392431 and T. harzianum IMI-392432, T. harzianum IMI392433 and T. harzianum IMI-392434 were collected from Biotechnology and Microbiology Laboratory, Department of Botany, Rajshahi University, Bangladesh. These strains were isolated from decomposed garbage and soil by Rahman (2009) and were previously verified by CABI Bioscience, Surrey, U.K.

\subsection{Isolation of pathogen from anthracnose disease of Chilli}

Isolates of $C$. capsici was isolated from infected fruit parts of chilli which was collected after proper noting down of the symptoms of the disease. Following standard phytopathological methods (Booth, 1971), pathogen was isolated from the transitional zone of healthy and infected tissues on Potato Dextrose Agar (PDA) medium. All isolates were tested for pathogenicity to chilli using Koch's Postulate. The most virulent isolate was chosen for further experimentation.

\subsection{Preparation and application of spore suspension}

Mycelial disc (5 $\mathrm{mm}$ dia.) of Trichoderma isolates and $C$. capsici were obtained from 4-5 days-old cultures and transferred to $50 \mathrm{ml}$ potato dextrose agar in a 250-ml conical flask separately and incubated at $28{ }^{\circ} \mathrm{C}$ for 7 days (Panahian et al., 2012; Cascino et al., 1990). After incubation, $30 \mathrm{ml}$ of sterile distilled water was added to each culture and the flasks were shaken at $50 \mathrm{rpm}$ for $30 \mathrm{~min}$ in an orbital shaker. Then the content of each conical flask was filtered through sterile muslin cloth. The culture filtrate with the spores was collected and a concentration of $4-5 \times 10^{5}$ spores $/ \mathrm{ml}$ was obtained by dilution with sterilized distilled water. The spore concentration were examined and ensured under compound microscope (Olympus CX21).

For seed treatment, 10 to 15 seeds were dipped, for about 20 minutes in the spore suspension $\left(5 \times 10^{5}\right.$ spores $\left./ \mathrm{ml}\right)$ obtained as mentioned and the treated seeds were dried inside the laminar air flow cabinet. After that in the same way Trichoderma treated and untreated seeds were again dipped in the spore suspension $\left(4 \times 10^{5}\right.$ spores $/ \mathrm{ml}$ ) of 7 days old culture of $C$. capsici for about 20 minutes and then the treated seeds were dried under laminar air flow hood. After germination of the treated seeds, $50 \mathrm{ml}$ of the conidial suspension of Trichoderma strains/species and $C$. capsici were poured individually and in mixture of both onto the potsoil of respective treatments at 7 days interval up to harvesting.

\subsection{Preparation and application of secondary metabolites}

$200 \mathrm{ml}$ of Richard's solution $\left(\mathrm{KNO}_{3}: 1.0 \mathrm{~g}, \mathrm{KH}_{2}\right.$ $\mathrm{PO}_{4}: 0.5 \mathrm{~g}, \mathrm{MgSO}_{4} 7 \mathrm{H}_{2} \mathrm{O}: 0.25 \mathrm{~g}$, glucose: $34 \mathrm{~g}$, trace amounts of $\mathrm{FeCl}_{3}$ in $1 \mathrm{~L}$ distilled water, $\mathrm{pH}$ 6.5) was prepared and poured into $500 \mathrm{ml}$ conical flasks and autoclaved for 15 minute at $121{ }^{\circ} \mathrm{C} / 1.05 \mathrm{~kg} / \mathrm{cm}^{2}$ pressure. Six pieces of agar discs $(6 \mathrm{~mm})$ were kept in a flask (with media) for each strains of Trichoderma and C. capsici separately with four replications. The flasks were incubated on a Gallenkamp orbital incubator at $100 \mathrm{rpm}$ at $28{ }^{\circ} \mathrm{C}$ (Dennis and Webster, 1971). The culture filtrates were collected after 30 days of incubation. These were then concentrated to about $50 \%$ using a vacuum evaporator at $38-40$ ${ }^{\circ} \mathrm{C}$ and finally filtered by sterilized membrane filter. For seed treatment, 10 to 15 seeds were dipped in the 30 days old filtrate secondary metabolites of each Trichoderma strains/species and the treated seeds were dried under laminar air flow hood. In the same way treated and untreated seeds were treated with secondary metabolites of $C$. capsici about 20 minutes and dried inside the laminar air flow. After germination of the treated seeds, $50 \mathrm{ml}$ of secondary metabolites of both Trichoderma and C. capsici were poured individually and in mixture of both onto the pot-soil of respective treatments at 7 days interval up to harvesting.

\subsection{Treatments and data analysis}

Five Trichoderma species/strains and one virulent isolate of $C$. capsici were used in this experiment. Trichoderma species/strains were $T$. 
virens IMI-392430, T. pseudokoningii IMI392431, T. harzianum IMI-392432, $T$. harzianum IMI-392433, T. harzianum IMI392434. Chilli plants were inoculated with $C$. capsici $\left(4 \times 10^{5}\right.$ spores $\left./ \mathrm{ml}\right)$ and Trichoderma species/strains $\left(5 \times 10^{5}\right.$ spores $\left./ \mathrm{ml}\right)$ in different suspension forms keeping one control (no treatment). Both Trichoderma species/strains and C. capsici were applied or inoculated separately as spore suspension and secondary metabolites. Moreover, spore suspension mixtures and secondary metabolites suspension mixtures of each Trichoderma species/strains with $C$. capsici were also applied as different treatment. Therefore, seven treatments, i.e. one $C$. capsici applied only as spores and secondary metabolites, while five Trichoderma were tested separately as spores, secondary metabolites and mixture of these spores or secondary metabolites with $C$. capsici in the chilli plant including nontreated one. Three replications of each treatment with factorial design of experiment were followed considering the suspension forms (or treatment types) as main plots and the causal pathogen and Trichoderma in the sub-plots. Statistical analysis was done with the help of computer package program SPSS (SPSS Inc., Chicago, IL, USA).

\subsection{Sampling and data collection}

Data on shoot length, number of primary branch, number of secondary branch and number of roots were recorded from 10 plants in each replication. These were measured at 90 days after sowing. Observations were also recorded for number of infected and total fruits per plant, dry fruit weight and yield per plant. Fresh fruit was dried in an oven at $95{ }^{\circ} \mathrm{C}$ for two hours first and then 72 hours at $65{ }^{\circ} \mathrm{C}$. Then dry weight was determined using electronic balance. Percentage of infected fruits was calculated through simple arithmetic calculation considering the recorded rotted fruits out of the total fruits observed.

The percentage of fruit yield increment was calculated from the difference of fruit yield between a specific treatment and non-treated one. Similar calculation was also done in case of disease increment or decrement.

\section{Results and Discussion}

\subsection{Percentage of fruit infection}

The highest percentage of infected fruit was recorded in spore suspension of $C$. capsici $(98.4 \%)$ and the lowest was recorded in spore suspension of $T$. harzianumIMI-392433 (4.2\%) (Fig. 1). In control (no treatment), a remarkable percentage $(12.5 \%)$ of infected fruit was also observed. Here infection source might be the seeds, or the environment or both. Application of spore suspension of $T$. harzianumIMI-392433 significantly $(\mathrm{p} \leq 0.05)$ suppressed the fruit infection $95.9 \%$ and $74.7 \%$ compared to the spore suspension of $C$. capsici and control respectively (Fig 1). Compare to the control the disease reduction was 66.2 and $65.4 \%$ respectively in spore suspension and secondary metabolites of $T$. harzianum. Wharton et al. (2012) reported that $T$. harzianum provided control of seed piece decay (caused by Phytophthora infestans) reducing disease incidence and severity on average by $73 \%$ and $86 \%$ respectively under optimal conditions and these were similar like fludioxonil + mancozeb, which reduced disease incidence and severity on average by $73 \%$ and $85.5 \%$ respectively. Antifungal metabolites extracted from $T$. harzianum showed markedly high inhibitory activities on spore germination and germ-tube growth of $C$. capsici (Rahman et al., 2013). In this study, biochemical analysis of antifungal secondary metabolites applied or produced after the application of spore suspension of Trichoderma, were not done. However, previous reports indicated that Trichoderma can produce harzianic acid, alamethicins, tricholin, peptaibols, antibiotics, 6-penthyl- $\alpha$-pyrone, massoilactone, viridin, glioviridin, gliovirin, glisoprenins, heptelidic acid, pentyl pyrone, gliotoxin, trichorzianines and oxazole which can increase growth of plants and induce resistance to disease (Di Pietro et al., 1993; Lee et al., 1995; Chet et al., 1997; Intana, 2003; Vey et al., 2001). Trichoderma inhibited the growth and 
pathogenicity of $C$ capsici in some other different ways like parasitism, competition for food and space, degradation of pathogenic enzymes like pectinage etc. through antibiotics, antifungal toxic metabolites, lytic enzymes etc. (Zimand et al., 1996). Biswas and Das (1999) reported that Trichoderma was found effective when used as seed coating against seedling disease. Prasad et al. (2002) found that soil treated with $T$. harzianum showed $61.5 \%$ disease control in chickpea while Kashem et al. (2005) observed $<30 \%$ disease control in lentil seed.

The effect of spore suspension and secondary metabolites irrespective of treatments were similar on the disease incidence. But disease incidence was significantly higher under high inoculum pressure i.e., when spore suspension or secondary metabolites of Trichoderma species/strains was mixed with $C$. capsici. In this case, the disease incidence ranged from 20.4-33.6\% in the $T$. harzianum strains and $38.6-48.0 \%$ in other tested Trichoderma species across the treatment types. On the other hand $C$. capsici treatment caused the highest fruit infection in spore suspension $(98.4 \%)$ followed by secondary metabolite $(82.7 \%)$. These results indicated that both conidial spores of $C$. capsici as well as its secondary metabolite effectively incited the disease, while, spores of $T$. harzianum strains and its secondary metabolites alone suppressed the disease effectively (average $65.8 \%$ disease reduction).

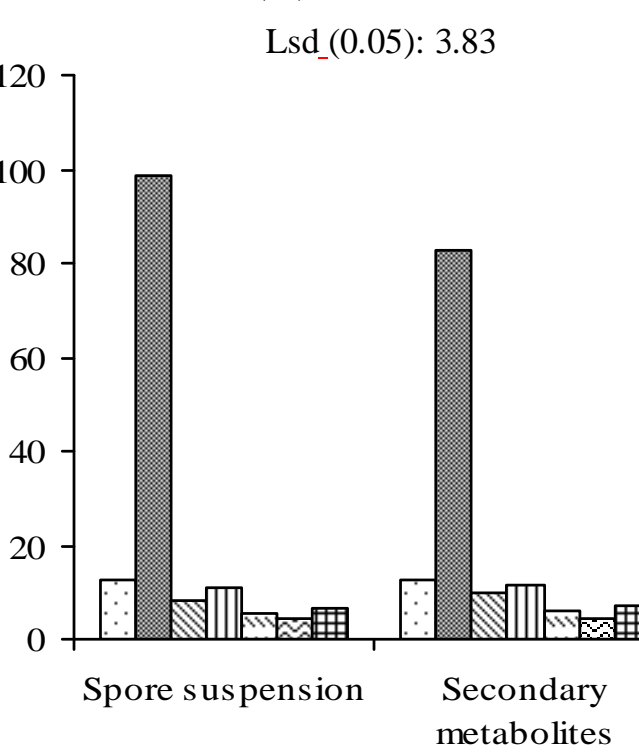

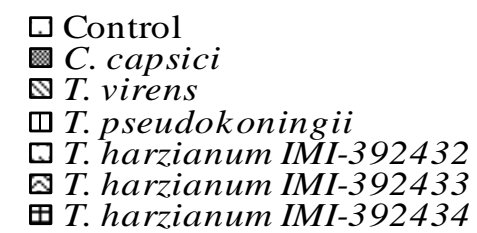

田 T. harzianum IMI-392434

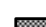

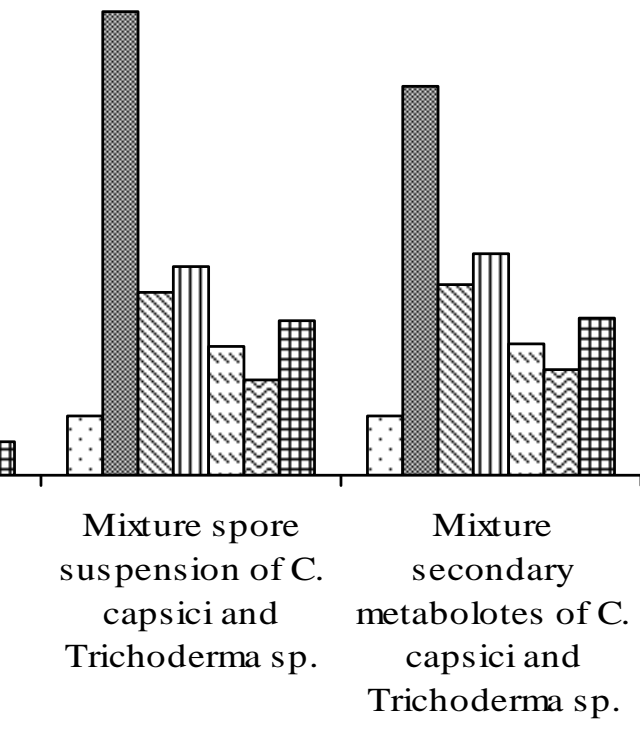

Fig. 1. Effect of Trichoderma strains on percentages of infected chilli fruit. Bar marked by the same letters are not significantly different $(\mathrm{p}<0.05)$ by DMRT analysis. 
The disease development by the pathogen and suppression of the disease by Trichoderma were dependent on the production level of their spores/secondary metabolites in the substrate level. Because, under high inoculum level of $C$. capsici the disease incidence increased and extent of disease control by Trichoderma depends to some extent on disease pressure. Many reports are available for successful use of antifungal metabolite extracted from Trichoderma spp. to control S. rolfsii causing disease on vegetables (Maiti et al., 1991), P. aphanidermatum causing wilt of cotton and watermelon (Ordentlich et al., 1992) and damping-off of cucumber (Intana, 2003) and Phytophthora sp. causing various plant diseases (Wilcox et al., 1992). This research indicated an additional successful use of antifungal metabolites from both $T$. harzianum wild type and mutant strains in controlling anthracnose on chilli fruits caused by $C$. capsici.

However, the spore and the secondary metabolites of $T$. harzianum strains influence and increase the growth of shoot, number of primary branches, number of secondary branches and number of roots, leaf and flower (detail data are not presented). Vigor of the plant and its disease resistance might also be increased with the metabolites of $T$. harzianum strains especially in $T$. harzianum IMI-392433. Recent studies indicated that some strains enhance plant growth and development. Yedidia et al. (2001) showed that treatment of cucumber plants in soil with $T$. harzianum (T-203) resulted in large increases in root area and cumulative root length, and significant increases in dry weight, shoot length, and leaf area over that of the untreated control.

\subsection{Shoot and root growth}

The shoot length of the chilli plant among the treatments varied significantly $(\mathrm{p}<0.05)$ (Table 1). The shoot length was similar and lower in both the control $(14.48 \mathrm{~cm})$ and $C$. capsici treatments (spore-13.98 cm, secondary metabolite- $14.47 \mathrm{~cm})$.

Table 1. Effect of Trichoderma on the shoot length $(\mathrm{cm})$ of chilli

\begin{tabular}{|c|c|c|c|c|}
\hline \multirow[b]{2}{*}{ Treatments* } & \multicolumn{4}{|c|}{ Treatment types } \\
\hline & $\begin{array}{c}\text { Spore } \\
\text { suspension }\end{array}$ & $\begin{array}{l}\text { Secondary } \\
\text { metabolites }\end{array}$ & $\begin{array}{c}\text { Mixture spore } \\
\text { suspension of } C \text {. } \\
\text { capsici and } \\
* * \text { Trichoderma } \text { sp. }\end{array}$ & $\begin{array}{c}\text { Mixture secondary } \\
\text { metabolotes of } C \text {. } \\
\text { capsici and } \\
\text { **Trichoderma }\end{array}$ \\
\hline Control & 14.48 & 14.48 & 14.48 & 14.48 \\
\hline C. capsici & 13.98 & 14.47 & 13.98 & 14.47 \\
\hline T. virens & 29.98 & 29.48 & 21.88 & 19.93 \\
\hline T. pseudokoningii & 28.78 & 27.54 & 18.67 & 17.69 \\
\hline T. harzianum IMI-392432 & 31.91 & 31.86 & 24.59 & 24.43 \\
\hline T. harzianum IMI-392433 & 32.95 & 32.83 & 26.56 & 25.46 \\
\hline T. harzianum IMI-392434 & 30.89 & 30.48 & 23.58 & 22.67 \\
\hline Lsd (0.05) & & & 0.93 & \\
\hline
\end{tabular}

*Number of spores of $C$. capsici and Trichoderma sp. were $4 \times 10^{5}$ and $5 \times 10^{5}$ spores $/ \mathrm{ml}$ suspension, respectively.

**Trichoderma $s p$. was not mixed with treatment $C$. capsiciin no forms of spore suspension or secondary metabolites.

Control: No treatment either with $C$. capsici and or Trichoderma sp. 
Trichoderma species, exhibited a significant increase in the height and dry weight of peper seedlings using 1/16 dilution in cell-free culture broths. These results proved that Trichoderma species produce substances in the cell-free culture filtrate responsible for these effects. Thus, they have a phytohormonal effect on pepper seedlings exhibiting the same growth enhancement as natural plant hormones (Brenner, 1981). The secondary metabolites are key facilitators of many of these positive effects. They act as microbe-associated molecular patterns (MAMPS) and as auxin-like analogues at low concentrations (Vinale et al., 2008). The number of primary branch, secondary branch per shoot and number of roots per plant at 90 days after sowing were found similar to the results of shoot length irrespective of treatment types. Only the effects of spore suspension on these parameters are shown in Table 2. T. harzianum IMI-392433 produced the highest number of primary branch, secondary branch and roots of chilli plants among the treatments.

\subsection{Number of fruits per plant}

The number of fruits/plant were found similar in case of spore suspension (5.13) and secondary metabolites (5.14) treated treatments of $C$. capsici (Table 3 ). The total number of fruits per plant ranged 22.32-38.96 and 20.18-36.39, respectively in spore suspension and secondary metabolites of Trichoderma treatments. But the number of fruits per plant was lower (10.4618.88) when spore suspension or (10.23-16.49) when secondary metabolites of Trichoderma was applied in mixing with $C$. capsici. This was because of high inoculum pressure of $C$. capsici and/or influenced by the activity of Trichoderma. Probably metabolites produced from Trichoderma were mainly used for the inactivation of $C$. capsici spores or secondary metabolites (Di Pietro et al., 1993; Lee et al., 1995; Chet et al., 1997; Intana, 2003; Vey et al., 2001). Hence, the physiological growth was not influenced much by Trichoderma and thereby less numbers of fruits were observed in the mixture of spore suspensions or secondary metabolites of Trichoderma and C. capsici. Further, under low or natural inoculum pressure, Trichoderma produced much more number of fruits because of its role in the higher physiological growth. It means, Trichoderma played its role in two ways. It might help the plant immunue system that resulted vigorous physiological growth of plants.

Table 2. The number of primary branch, secondary branch and roots per plant in spore suspension of different Trichoderma species/strains.

\begin{tabular}{lccc}
\hline Treatments* & $\begin{array}{c}\text { Number of primary } \\
\text { branch/plant }\end{array}$ & $\begin{array}{c}\text { Number of secondary } \\
\text { branch/plant }\end{array}$ & $\begin{array}{c}\text { Number of } \\
\text { roots/plant }\end{array}$ \\
\hline Control & $2.69 \mathrm{f}$ & $65.51 \mathrm{f}$ & $35.91 \mathrm{f}$ \\
C. capsici & $2.54 \mathrm{~g}$ & $64.43 \mathrm{~g}$ & $32.37 \mathrm{~g}$ \\
$T$. virens & $5.71 \mathrm{~d}$ & $97.36 \mathrm{~d}$ & $52.14 \mathrm{~d}$ \\
$T$. pseudokoningii & $4.54 \mathrm{e}$ & $93.48 \mathrm{e}$ & $50.38 \mathrm{e}$ \\
$T$. harzianum IMI-392432 & $6.96 \mathrm{~b}$ & $104.91 \mathrm{~b}$ & $58.37 \mathrm{~b}$ \\
$T$. harzianum IMI-392433 & $7.89 \mathrm{a}$ & $108.87 \mathrm{a}$ & $62.52 \mathrm{a}$ \\
$T$. harzianum IMI-392434 & $5.89 \mathrm{c}$ & $101.48 \mathrm{c}$ & $55.38 \mathrm{c}$ \\
\hline
\end{tabular}

Means following the same letter in a column did not differ significantly among the treatment types by DMRT at 5\%. *Number of spores of $C$. capsici and Trichoderma sp. were $4 \times 10^{5}$ and $5 \times 10^{5}$ spores $/ \mathrm{ml}$ suspension, respectively. **Trichoderma $s p$. was not mixed with treatment $C$. capsiciin no forms of spore suspension or secondary metabolites. Control: No treatment either with $C$. capsici and or Trichoderma $s p$. 
Table 3. The number of fruits produced per plant in different treatment types of Trichoderma

\begin{tabular}{lcccc}
\hline & \multicolumn{3}{c}{ Treatment types } \\
\cline { 2 - 5 } Treatments* & $\begin{array}{c}\text { Spore } \\
\text { suspension }\end{array}$ & $\begin{array}{c}\text { Secondary } \\
\text { metabolites }\end{array}$ & $\begin{array}{c}\text { Mixture spore } \\
\text { suspension of } C \text {. } \\
\text { capsici and } \\
* * \text { Trichoderma sp. }\end{array}$ & $\begin{array}{c}\text { Mixture secondary } \\
\text { metabolites of } C \\
\text { capsici and } \\
\text { **Trichoderma }\end{array}$ \\
\hline Control & 7.48 & 7.48 & 7.48 & 7.48 \\
C. capsici & 5.13 & 5.14 & - & - \\
T. virens & 26.34 & 24.94 & 11.19 & 10.86 \\
T. pseudokoningii & 22.32 & 20.18 & 10.46 & 13.23 \\
$T$. harzianum IMI-392432 & 34.26 & 32.94 & 14.18 & 16.49 \\
T. harzianum IMI-392433 & 38.96 & 36.39 & 18.88 & 12.86 \\
T. harzianum IMI-392434 & 30.48 & 28.98 & 13.12 & \\
Lsd (0.05) & & & 7.06 & \\
\hline
\end{tabular}

*Number of spores of C. capsici and Trichoderma sp. were $4 \times 10^{5}$ and $5 \times 10^{5}$ spores $/ \mathrm{ml}$ suspension, respectively. **Trichoderma $s p$. was not mixed with treatment $C$. capsiciin no forms of spore suspension or secondary metabolites. Control: No treatment either with C. capsici and or Trichoderma sp.

Table 4. Dry weight (g) of fruit in different treatment types of Trichoderma

\begin{tabular}{lcccc}
\hline & \multicolumn{3}{c}{ Treatment types } \\
\cline { 2 - 5 } Treatments* & $\begin{array}{c}\text { Spore } \\
\text { suspension }\end{array}$ & $\begin{array}{c}\text { Secondary } \\
\text { metabolites }\end{array}$ & $\begin{array}{c}\text { Mixture spore } \\
\text { suspension of } C . \\
\text { capsici and } \\
\text { **Trichoderma sp. }\end{array}$ & $\begin{array}{c}\text { Mixture secondary } \\
\text { metabolites of } C \text {. } \\
\text { capsici and } \\
\text { **Trichoderma }\end{array}$ \\
\hline Control & $0.38(2.99)$ & $0.38(2.99)$ & $0.38(2.99)$ & $0.38(2.99)$ \\
C. capsici & $0.32(2.54)$ & $0.36(2.61)$ & - & - \\
T. virens & $0.82(11.43)$ & $0.78(11.26)$ & $0.56(3.96)$ & $0.52(3.88)$ \\
T. pseudokoningii & $0.76(10.36)$ & $0.76(9.54)$ & $0.48(3.54)$ & $0.46(3.28)$ \\
T. harzianum IMI-392432 & $0.97(13.96)$ & $0.96(13.86)$ & $0.66(5.89)$ & $0.64(5.28)$ \\
T. harzianum IMI-392433 & $0.99(15.17)$ & $0.98(14.89)$ & $0.71(6.83)$ & $0.69(6.43)$ \\
T. harzianum IMI-392434 & $0.91(12.84)$ & $0.89(11.96)$ & $0.63(4.26)$ & $0.61(4.18)$ \\
Lsd (0.05) & & & 0.03 & \\
\hline
\end{tabular}

*Number of spores of $C$. capsici and Trichoderma $s p$. were $4 \times 10^{5}$ and $5 \times 10^{5}$ spores $/ \mathrm{ml}$ suspension, respectively. **Trichoderma $s p$. was not mixed with treatment $C$. capsiciin no forms of spore suspension or secondary metabolites. Control: No treatment either with $C$. capsici and or Trichoderma $s p$. Each figure indicates the dry weight of five fruits $(\mathrm{g})$. Figures within parenthesis indicate fresh weight $(\mathrm{g})$ of five fruits.

The other way could be the inactivation of the pathogen and/or its metabolites. Under low or natural inoculum pressure of $C$. capsici, the first mechanism showed more active that resulted good physiological growth of chilli plants. The second mechanism was more activate under high inoculum pressure of $C$. capsici, where antipathogenic activity of Trichoderma might suppressed the mycelial growth of $C$. capsici as well as influenced the physiological growth of chilli plant. All the Trichoderma species/strains produced higher number of fruits compare to the 
control and $C$. capsici treatments in low or natural inoculum pressure. But all Trichoderma species/strains produced similar number of fruits by above mentioned treatments except for $T$. harzianum IMI-392433 under epidemic condition. The total number of fruit per plant was the highest in all the treatments of $T$. harzianum IMI-392433. Among the treatments, spore suspension of $T$. harzianum IMI-392433 increased the number of fruits $76.7 \%$ and $67.8 \%$ per plant compared to spore suspension of $C$. capsici and control treatments respectively.

\subsection{Fruit weight (dry)}

Fruit weight (dry) was found higher in all the Trichoderma species/strains treatments including spore suspension and secondary metabolite treatments (Table 4). Further mixture suspension of Trichoderma with $C$. capsici showed lower fruit weight compare to the spore suspension or secondary metabolite of Trichoderma species/strains. The highest dry weight was recorded in T harzianum IMI 329433 followed by IMI-392432 in all the treatment types. The lowest dry weight was observed in diseased control followed by control. Among the treatments, spore suspension of $T$. harzianum IMI-392433 increased the dry weight of fruit $49.6 \%$ and $44.5 \%$ compared to spore suspension of $C$. capsici and absolute control treatments, respectively (Table 4).

\subsection{Fruit yield}

The yield per plant among the treatments ranged from 1.98-22.12 $\mathrm{g}$ in spore suspension and 2.12$20.37 \mathrm{~g}$ in secondary metabolites (Fig. 2).

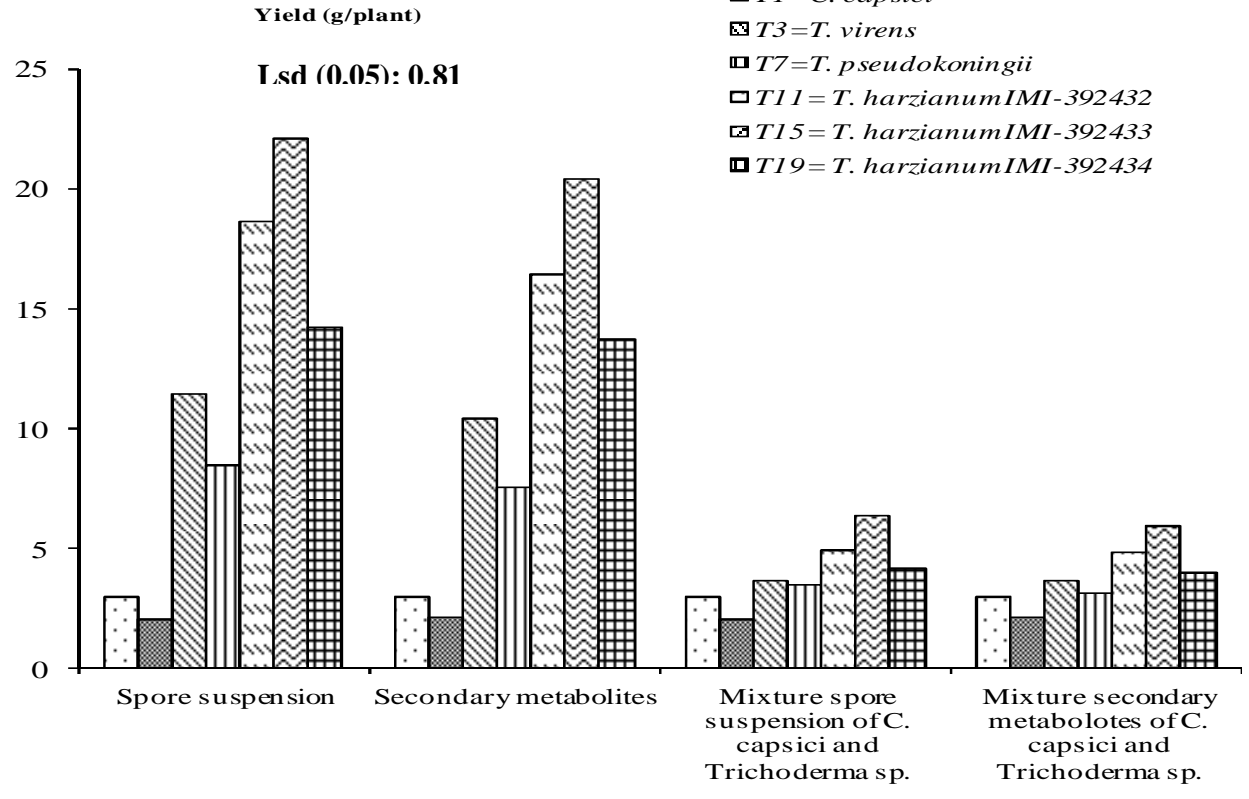

Fig. 2. Dry weight of fruit yield of Chilli in different treatments of Trichoderma species/strains 
Rahman et al. /The Agriculturists 16(2): 75-87 (2018)

The highest yield in the spore suspension $(22.12$ g) was similar to secondary metabolite $(20.37 \mathrm{~g})$ treatments of $T$. harzianum IMI-392433. The lowest yield was recorded in the $C$. capsici followed by control treatments of both spore suspension and secondary metabolites. All $T$. harzianum strains produced higher yield compare to two other Trichoderma species $T$. virens and $T$. pseudokoningii across the treatment types. Further, compare to the treatment of Trichoderma species/strains as spore suspension or secondary metabolites, fruit yield was lower under high inoculum pressure i.e., when Trichoderma applied in mixing with C. capsici. Here, mixture of spore suspension treatment produced 3.48-6.34 g while mixture of secondary metabolites produced 3.12-5.92 g fruit per plant.

Among the treatments, spore suspension of $T$. harzianum IMI-392433 increased the fruit yield $83.6 \%$ and $76.5 \%$ per plant compared to spore suspension of $C$. capsici and control treatments, respectively. The results reveal that the yield was significantly influenced by the application of $T$. harzianum IMI-392433. Many workers found higher yields compared to control when seeds treated with T. harzianum. Sultana (1999) obtained up to $81.60 \%$ higher seed yield of lentil when they were treated with $T$. harzianum for controlling foot and and root rot. Da Luz et al. (1998) also observed that yields of wheat seeds infected with Pyrenophora tritici-repentis, were significantly increased after application of $T$. virens.

Trichoderma species have shown direct effects on the chilli plant host. These effects include increased growth, yield as well as immunity against disease. Harman et al. (2004) also mentioned these effects including increased nutrient uptake, germination percentage, stimulation of plant immunity, defense against biotic and abiotic threats, and increased efficiency of fertilizer uptake. Trichoderma which is endophytic plant symbionts conferred inductin of increased nitrogen use efficiency in plants and reduce $\mathrm{N}$ application rate by $30-50 \%$ without reduction in yield (Harman 2011, Shoresh et al. 2010). Therefore, the increase in plant height, shoot and root dry weight and yield was due to higher $\mathrm{N}$ use efficiency by the plants treated with Trichoderma spp. Trichoderma spp. is one of the important groups of rhizosphere microorganisms, which can impart some beneficial effects on promoting plant growth and development (Harman et al., 2004; Qi and Zhao, 2013). The Trichoderma species have also been known to be used by plants as biological control agents for controlling different species of plant fungus diseases for decades (Harman et al., 2004).

\section{Conclusions}

From the above findings and discussion it may be concluded that the number of fruits and yield of chilli can be increased with the application of spore suspension of $T$. harzianum IMI-392433 which produces vigorous plant growth, increases the number of primary branches, secondary branches and roots. These attributes was due to beneficial effects of $T$. harzianum IMI-392433 that might be increased nutrient uptake and phytohormonal effect which act as auxin-like analogues at low concentration in chilli plants (Brenner, 1981, Vinale et al., 2008). It may also effectively control fruit rot of chilli caused by $C$. capsici through inactivation of fungal spores or secondary metabolites as well as host resistance (Di Pietro et al., 1993; Lee et al., 1995; Chet et al., 1997; Vey et al., 2001; Intana, 2003). Therefore, T. harzianum IMI-392433 may be used as an effective bio control agent to control C. capsici that causes fruit rot of chilli in Bangladesh.

\section{Acknowledgements}

The authors are expressing their special thanks to the Spices Research Centre, BARI, Borga and Department of Botany, Rajshahi University for nice cooperation. 


\section{References}

Abdul-Baki A. and Anderson JD. 1973. Vigour determination of soybean seed by multiple criteria. Crop Sci. 3: 630-633.

Baker R. Pautilz, TC. 1996. Theoretically basis for microbial interactions leading to biological control of soil borne plant pathogens. In: Principles and practice of managing soil borne plant pathogens. R. Hall (Ed.). The American Phytopathological Society. St. Paul. MN. Pp: 50-79.

Barua H., Rahman MM., Masud MM. 2009. Effect of storage containers environment at different storage period on the quality of chilli seeds. Int. J. Sustain. Crop. Prod. 4(4): 28-32.

Begum MF., Rahman MA., Alam MF. 2010. Biological control of Alternaria fruit rot of chilli by Trichoderma species under field conditions. Mycobiology 38 (2):113117.

Biswas KK., Das ND. 1999. Biological control of pigeon pea wilt caused by Fusarium udum with Trichoderma spp. Annals. Plant. Protection. Sci. 7(1): 46-50.

Booth C. 1971. The genus Fusarium. Commonwealth Mycol. Inst. Kew, Surrey, England.

Brenner ML. 1981. Modern methods for plant growth substance analysis. Ann Rev Plant Phys. 32: 511-538

Cascino JJ., Harris, R. F., Smith C. S., and Andrews J. H. 1990. Spore Yield and Microcycle Conidiation of Colletotrichum gloeosporioides in Liquid Culture. Applied and Environmental Microbiology, p. 2303-2310.

Chang YC., Baker R., Kleifield O., Chet I. 1986. Increased growth of plants in the presence of the biological control agent $T$. harzianum. Plant. Disease. 70:145-148.
Chet I., Inbar J., Hadar I. 1997. Fungal antagonists and mycoparasites. In The Mycota IV: Environmental and microbial relationships. ed. D.T. Wicklow, B. Söderström. 165-184. Springer-Verlag, Berlin.

Da Luz WC., Bergstrom GC., Stockwell C.A. 1998. Seed applied bioprotectents for control of seed-borne Pyrenophora triticirepentis and agronomic enhancement of wheat. Can. J. Plant. Pathol. 19: 384-386.

Di Pietro A., Lorito M., Hayes CK., Broadway RM. Haman EL. 1993. Endochitinase from Gliocla- dium virens: isolation, characterization, and synergistic antifungal activity in combination with gliotoxin. Phytopathology 83:308-313.

Dennis C., Webster J. 1971. Antagonistic properties of species-group of Trichoderma I. Production of non-volatile antibiotics. Trans. Brit. Mycol. Soc. 57:25-39.

Elad Y. 1994. Biological control of grape grey mold by Trichoderma harzianum. Crop. Prot. 13: 35-38.

Etabarian HR. 2006. Evalution of Trichoderma isolates for biological control of charcoal stem rot in melon caused by Macrophomina phaseolina. J. Agric. Sci. Technol. 8:243-250

Eziashi EI., Omamor IB Odigie EE. 2007. Antagonism of Trichoderma viridie and effects of extracted water soluble compounds from Trichoderma species and benlate solution on Ceratocystis paradoxa. African J. Biotech.6:388-392

Hanson L E. 2000. Reduction of verticillium wilt symptoms in cotton following seed treatment with Trichoderma virens. The Journal of Cotton Science. 4: 224-231.

Harman GE. 2000. Myths and dogmas of biocontrol. Changes in perceptions derived from research on Trichoderma harzianum T-22. Plant Dis. 84: 377-393. 
Harman GE., Howell CR., Viterbo A., Chet I., Lorito M. 2004. Trichoderma speciesopportunistic, avirulent plant symbionts. Nat. Rev. Microbiol. 2 43-56.

Harman GE. 2011. Multifunctional Fungal Plant Symbionts: New tools to enhance plant growth and productivity. New Phytology. 189, 647-649.

Hjelijord LG., Stensvand A. and Transmo A. 2001. Antagonism of nutrient- activated conidia of Trichoderma harzianum (airoviridae) P1 against Botrytis cinera. Phytopathol. 91: 1172-1180.

Intana W. 2003. Selection and development of Trichoderma spp. for high glucanase, antifungal metabolite producing and plant growth promoting isolates for biological control of cucumber damping-off caused by Pythium spp. [Ph.D Thesis] Kasetsart University, Thailand.

Kashem MA., Naznin HA., Islam MM., Jalaluddin M., Hossain I. 2005. Effect of different methods of application of Trichoderma in controlling foot and root rot of lentil. Bangladesh. J. Seed. Sci. Tech. 9 (1\&2): 39-42.

KüçüK C., Kivanç M. 2003. Isolation of Trichoderma spp. and determination of their antifungal, biochemical and physiological features. Turk. J. Biol. 27: 247-253.

Lo CT., Lin CY. 2002. Screening strains of Trichoderma spp. for plant growth enhancement in Taiwan. Plant Pathol Bull. 11:215-20.

Lee C., Chung M., Lee H., Kho Y. 1995. MR93A, a new oxazole from Trichoderma harzianum KCTC 0114BP. J. Nat. Prod. 58:1605-1607.

Maiti D., Dasgupta B., Sen C. 1991. Antagonism of Trichoderma harzianum and Gliocladium virens isolates to Sclerotium rolfsii and biological control of stem rot of groundnut and betel vine. Journal of Biological Control5, 105-109.
Mukhtar I. 2008 Influences of Trichoderma species on seed germination in okra. Mycopath. 6(1\&2):47-50.

Ordentlich A., Z Wiesman HE., Gottlieb M., Cojocaru Chet I. 1992. Inhibitory furanone produced by the biocontrol agent Trichoderma harzianum. Phytochemistry. 31:485-486.

Ozbay N., Newman SE. 2004. Biological control with Trichoderma spp. with emphasis on T. harzianum. Pak J Biol Sci 7:478-84.

Panahian Gh., Rahnama K., Jafari M. 2012. Mass production of Trichoderma spp and application. Intl. Res. J. of Applied and Basic Sciences. Vol., 3 (2), 292-298.

Pakdeevaraporn P., Wasee S., Taylor PWJ., Mongkolporn O. 2005. Inheritance of resistance to anthracnose caused by Colletotrichum capsici in Capsicum. Plant Breeding, 124(2):206-208.

Prasad RD., Rangeshwaran R., Anuroop CP., Rashmi HJ. 2002. Biological control of wilt and root rot of chickpea under field conditions. Ann. Plant.Protect.Sci. 10(1):72-75.

Qiu ZB., Li JT., Zhang MM., Bi ZZ., Li ZL. 2013. He-Ne laser pretreatment protects wheat seedlings against cadmium-induced oxidative stress. Ecotoxicol. Environ. Saf. 88 135-141.

Rahman MA.2009. Screening of Trichoderma spp. and their efficacy as a bioconversion agent of municipal solid waste through appropriate technique of solid state fermentation. Ph.D thesis, Department of Botany, University of Rajshahi, Rajshahi6205, Bangladesh.

Rahman MA., Razvy MA. , Alam MA. 2013. Antagonistic activities of Trichoderma strains against chilli anthracnose pathogen. IJMM 1(1): 7-22. (http://www.innspub.net)

Ramachandran N, Madhavi RK, Rathnamma K. 2007. Current Status of Chilli 
Anthracnose in India. Abstracts of the First International Symposium on Chilli Anthracnose. National Horticultural Research Institute, Rural Development of Administration, Republic of Korea.

Samuels GJ. 1996 Tricoderma: A review of biology and systematics of the genus. Mycol. Res. 100: 923-935.

Shake MU. 2006 Studies on sheath blight disease of Rice (Oryza sativa L.) caused by Rhizoctonia solani and its control. M. Sc. thesis. Department of Botany, University of Rajshahi, Rajshahi, Bangladesh.

Shoresh., M., Mastouri F., Harman GE. 2010. Induced systemic resistance and plant responses to fungal biocontrol agents. Annual Review of Phytopathology. 48:2143.

Shoresh M, Mastouri, F., and Harman G. E. 2010. Induced systemic resistance and plant responses to fungal biocontrol agents. Annual Review of Phytopathology. 48, 21-43.

Soytong K, Srinon W, Rattanacherdchai K, Kanokmedhakul $\mathrm{S}$ and Kanokmedhakul K. 2005. Application of antagonistic fungi to control anthracnose disease of grape. Journal of Agricultural Biotechnology 1: 33-41.

Sultana N. 1999. Biological control of foot and root rot of lentil with Trichoderma harzianum. MS thesis, Department of Plant Pathology, Bangladesh Agricultural University, Mymensingh., Bangladesh.

Sumitra R., Gaikward SJ. 1995. Cheecking Fusarium wilt of pigeon pea by Biological Means. J. Soil. Crop. 5(2): 163-165.

Vey A., Hoagland RE., Butt TM. 2001. Toxic metabolites of fungal bio control agents. In: Butt T.M., Jackson C., Magan N. (eds): Fungi as bio control agents: Progress, problems and potential. CAB International, Bristol. 311-346.
Vinale F., Sivasithamparam K., Ghisalberti EL., Marra R., Barbetti M.J., Li H., Lorito M. 2008. A novel role for Trichoderma secondary metabolites in the interactions with plants. Physiol Mol Plant Pathol. 72(1-3): 80-86.

Watanabe, N. 1993. Promoting effect of Trichoderma spp. on seed germination and plant growth in vegetable. Mem. Inst. Sci. Tech. Meiji. Univ. 32(2):9-18.

Wharton PS., Kirk WW. , Schafer RL., Tumbalam P. 2012. Evaluation of biological seed treatments in combination with management practices for the control of seed-borne late blight in potato. Biological Control. 63 (3): 326-332.

Wilcox WF, Harman GE, Di Pietro A. 1992. Effect of gliotoxin on growth, sporulation, and zoospore motility of seven Phytophthora spp. in vitro. Phytopathology.82, 11-21.

Windham MT., Elad Y. , Baker R. 1986. A mechanism for increased plant growth induced by Trichoderma spp.Phytopathology.76: 518-521.

Yedidia I., Benhamou N., Chet I. 1999. Induction of defense responses in cucumber plants (Cucumis sativus L.) by the biocontrol agent Trichoderma harzianum. Appl. Environ. Microbiol. 65: 1061-1070.

Yedidia I., Benhamou N., Kapulnik Y., Chet I. 2000. Induction and accumulation of PR proteins activity during early stages of root colonization by the mycoparasite Trichoderma harzianum strain T-203. Plant Physiol. Biochem. 38:863-873.

Yedidia I., Srivastva AK., Kapulnik Y., Chet I. 2001. Effect of Trichoderma harzianum on microelement concentrations and increased growth of cucumber plants. Plant Soil 235:235-242.

Zimand G., Eland Y., Chet I. 1996. Effect of Trichoderma harzianum on Botrytis cinerea pathogenecity. Phytopathology 86: $1255-1260$. 